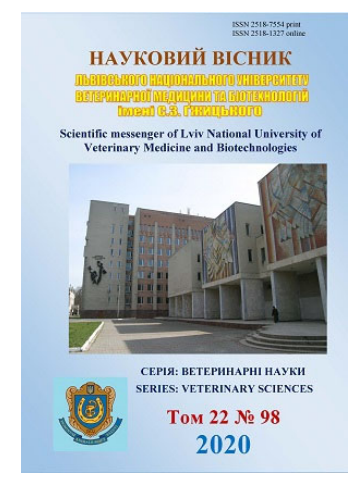

\author{
Науковий вісник Дьвівського національного університету \\ ветеринарної медицини та біотехнологій імені С.3. Гжицького. \\ Серія: Ветеринарні науки \\ Scientific Messenger of Lviv National University \\ of Veterinary Medicine and Biotechnologies. \\ Series: Veterinary sciences
}

UDC 619:639.3:637.047

\title{
Assessment of macrocyclic lacton group products for ectoparasitosis of carp
}

\author{
Yu. V. Loboiko, Ye. O. Barylo, B. S. Barylo \\ Stepan Gzhytskyi National University of Veterinary Medicine and Biotechnologies Lviv, Ukraine
}

Article info

Received 09.03.2020

Received in revised form 13.04 .2020

Accepted 14.04.2020

Stepan Gzhytskyi National University of Veterinary Medicine and Biotechnologies Lviv, Pekarska Str., 50, Lviv, 79010, Ukraine. Tel.: +38-097-552-07-04 E-mail:llobojko@ukr.net
Loboiko, Yu. V., Barylo, Ye. O., \& Barylo, B. S. (2020). Assessment of macrocyclic lacton group products for ectoparasitosis of carp. Scientific Messenger of Lviv National University of Veterinary Medicine and Biotechnologies. Series: Veterinary sciences, 22(98), 16-21. doi: 10.32718/nvlvet9803

The material for the study were Lubin carp of one year old spontaneously invaded by the ectoparasites Lernaea cyprinacea and Dactylogyrus vastator. For the experiment we used drugs: "Brovermectingranulate" (development of "BFP" serial production; $1 \mathrm{~g}$ of the preparation contains: active substance (ADR) ivermectin - $3.5 \mathrm{mg}$; tocopherol acetate $(20 \mathrm{mg})$ and Emamectin benzoate (manufactured by King Quenson Industry Group; $1 \mathrm{~g}$ of preparation contains ADR emamectin benzoate (50 mg). Analyzing morphological, biochemical and immunological parameters of blood and organs of fish, it is possible to state that the fact that the anti-parasitic drugs "Brovermectin granulate" and "Emamectin benzoate" has a pronounced antiparasitic effect, normalizing the homeostasis of the body. The results obtained showed significant fluctuations in the number neutrophils, eosinophils and lymphocytes. In ectoparasites infested of fishes used for macrocyclic lactones, y leukocyte formula sharply increases the percentage of rod-shaped neutrophils and at the same time decreases the proportion of lymphocytes. At the same time, there is an increase in the number of eosinophils that perform the function of protecting the body of fish from parasites. Eosinophilia, as in the higher vertebrates, is one of objective indicators of allergy (sensitization) of the body, nature the course of inflammatory processes. The results obtained indicate a decrease in the production of total T-lymphocytes are cells that play a key role in the immune system protection in the body of carp for damage by ectoparasites. In analyzing the above data, attention is drawn to the lower functional the activity of the blood T-lymphocyte system in ectoparasites infested with fish, than those given antiparasitic drugs. From this it follows that the ability of the blood lymphocytes of the fish to which the drugs from the group were given of macrocyclic lactones, before pathogen binding and production of antigens the antibodies that neutralize them are much higher than the fish affected ectoparasites. The immune system in fish provides self-regulation through direct contact of cells (macrophages, neutrophils, cytotoxic T-lymphocytes) as well as due to humoral factors (lysozyme, complement). The use of drugs from the group of macrocyclic lactones promotes the release of infested fish from ectoparasites with the following normalization of their life, increase of immune status and resistance.

Key words: macrocyclic lacton, ectoparasites, Lernaea cyprinacea, Dactylogyrus vastator.

\section{Оцінка препаратів групи макроциклічних лактонів за ектопаразитозів коропа}

Ю. В. Лобойко, Є. О. Барило, Б. С. Барило

Львівський наџіональний університет ветеринарної медицини та біотехнологій імені С. 3. Гжиџького, м. Львів, Украӥна

Матеріалом для дослідження були однорічки любінського лускатого коропа, спонтанно інвазовані ектопаразитами Lernaea cyprinacea ma Dactylogyrus vastator. Для досліду використовували препарати: “Бровермектин-гранулят” (розробка НВФ “Бровафарма" серійного виробництва; 1 г препарату містить: активно діючу речовину (АДР) івермектин - 3,5 мг; токоферол ацетат - 20 мг) і “Емамектин-бензоат” (виробництво King Quеnson Industry Group; 1 г препарату містить AДP емамек- 
тин-бензоат - 50 мг). Аналізуючи морфологічні, біохімічні та імунологічні показники крові та органів риб, можна констатувати, щцо протипаразитарні препарати “Бровермектин-гранулят" та “Емамектин-бензоат” виявляють виражену антипаразитарну дію, нормалізуючи гомеостаз організму. Отримані результати показали вірогідні коливання кількості нейтрофілів, еозинофілів та лімфоцитів. У інвазованих ектопаразитами риб, яким застосовували препарати з групи макрочиклічних лактонів, у лейкоциттарній формулі різко зростає відсоток паличкоядерних нейтрофілів і одночасно знижується частка лімфочитів. Водночас відбувається зростання кількості еозинофілів, які виконують функцію захисту організму риб від паразитів. Еозинофілія, як $і$ у вищих хребетних, є одним з об'єктивних показників алергізації (сенсибілізації) організму, характеру перебігу запальних процесів. Одержані результати свідчать про зменшення продукиіі загальних Т-лімфоцитів - клітин, які відіграють ключову роль у системі імунного захисту в організмі коропа за ураження ектопаразитами. При аналізі наведених даних привертає увагу нижча функціональна активність системи Т-лімфочитів крові у інвазованих ектопаразитами риб, ніж у тих, яким задавали протипаразитарні препарати. 3 цьього випливає, що здатність лімфоцитів крові риб, яким задавали препарати з групи макрочиклічних лактонів, до зв'язування антигенів патогенів і продукції антитіл, які їх знешкоджують, значно вища, ніж у риб, уражених ектопаразитами. Імунна система у риб забезпечує саморегуляиію за допомогою безпосереднього контакту клітин (макрофагів, нейтрофілів, ичитотоксичних Т-лімфочитів), а також завдяки гуморальним факторам (лізоциму, комплементу). Застосування препаратів з групи макрочиклічних лактонів сприяє звільненню інвазованих риб від ектопаразитів з подальшою нормалізацією їхньої життєдіяльності, підвищенню імунного статусу і резистентності.

Ключові слова: макроциклічні лактони, ектопаразити, Lernaea cyprinacea, Dactylogyrus vastator.

\section{Вступ}

Значних збитків при вирощуванні коропових риб завдають ектопаразитарні хвороби. Доведено, що епізоотичний стан водойм суттєво впливає на їхню рибопродуктивність, а успішність заходів боротьби 3 інвазійними хворобами риб залежить від наявності на фармацевтичному ринку високоефективних протипаразитарних засобів (Horsberg, 2012; Loboiko \& Danko, 2015; Loboiko et al., 2016).

Відносно недавно, поряд із синтетичними піретроїдами і похідними бензімідазолу, для практики ветеринарної медицини були запропоновані макроциклічні лактони. Авермектини за структурою належать до класу макроциклічних лактонів (Tisler \& Kozuh-Erzen, 2006; Horsberg, 2012). Препарати синтезовані на основі авермектину володіють високою протипаразитарною активністю (Hemaprasanth et al., 2012; Veldhoen, 2012; Loboiko et al., 2016), тому метою нашої роботи було з'ясувати ефективність терапії лернеозу та дактилогірозу коропа шляхом застосування антипаразитарних препаратів з групи макроциклічних лактонів “Бровермектин-гранулят" та "Емамектин-бензоат" i визначення їх впливу на показники крові та органів риб.

\section{Матеріал і методи досліджень}

Матеріалом для дослідження були однорічки любінського лускатого коропа масою 53-55 г, з яких 6 екз. були клінічно здоровими (контроль) та 18 екз. (дослід) - спонтанно інвазованими $L$. cyprinacea та D. vastator. За результатами визначення рівня інвазованості останніх їх поділили на три аналогічні групи $(\mathrm{n}=6)$. Всі риби були уражені L. cyprinacea та D. vastator 3 II від 0,11 до 0,26 лерней на 1 грам маси тіла та 0,29-0,53 дактилогірусів на грам маси тіла. Риб усіх груп утримували у 4 акваріумах ємністю 40 дм $^{3}$ зі штучною аерацією за температури $18-20{ }^{\circ} \mathrm{C}$. Догляд та годівлю їх проводили згідно з відповідними нормами та раціонами. Впродовж усього періоду досліджень проводили спостереження за поведінкою та клінічним станом риб. Переддослідний період адаптації риб становив 14 діб.
Введення препаратів проводили перорально за допомогою зонду в передній відділ кишечнику: "Бровермектин-гранулят" 1 раз на добу дві доби поспіль, "Емамектин-бензоат" 1 раз на добу впродовж семи діб. Для цього визначену дозу препаратів вносили до 1 мл $2 \%$ крохмального клейстеру, а саме: для дослідної групи № 2 - "Бровермектин-гранулят" - по 60 мг/кг маси тіла; для дослідної групи № 3 "Емамектин-бензоат" - по 10 мг/кг маси тіла. Рибам контрольної групи та дослідної групи № 1 водночас вводили лише по 1 мл $2 \%$ клейстеру.

На 14 добу після закінчення введення препаратів провели паразитологічний огляд риб і відбір проб крові та тканин для досліджень. Визначали гематологічні показники (Dekhtiarov, 2008), загальний білок сироватки крові та фракційний склад (Kondrahin, 1985), лейкограму крові (Ivanov et al., 2003), загальну кількість Т-лімфоцитів і кількість окремих їх субпопуляцій, а також кількість В-лімфоцитів (Novikov \& Novikova, 1979). Активність аспартат- (АсATК.Ф.2.6.1.1) і аланін-амінотрансфераз (АлАТК.Ф.2.6.1.2) (Osadchaja, 1982). У крові риб досліджували бактерицидну (Vlizlo, 2012), лізоцимну (Dorofejchuk, 1968) i фагоцитарну (Chumachenko, 1990) активність.

Іхтіопаразитологічний аналіз проводили за методом неповного паразитологічного розтину за I. Є. Биховською-Павловською (Byhovskaja-Pavlovskaja, 1985). Видову належність паразитів визначали за "Определителем паразитов пресноводных рыб фауны СССР” (Bauer, 1987).

Інтенсивність інвазії (II) визначали шляхом підрахунку кількості паразитів на тілі та зябрах досліджуваної риби.

\section{Результати та їх обговорення}

За вивчення патогенної дії ектопаразитів та препаратів з групи макроциклічних лактонів на показники крові риб нами встановлено, що за змішаної інвазії кількість еритроцитів була меншою, порівняно з контролем, у крові риб 2-ї дослідної групи на 47,9 \% $(\mathrm{P}<0,01)$. Незначне зниження кількості еритроцитів виявлено також за застосування препаратів “Бровер- 
мектин-гранулят" та "Емамектин-бензоат", проте вірогідних змін не встановлено (табл. 1).

За змішаної інвазії, поряд із зниженням кількості еритроцитів, зменшується вміст гемоглобіну в крові коропів. У 2-й дослідній групі вміст гемоглобіну крові становив 76,22 $\pm 2,54$ проти 85,64 $\pm 2,45$ г/л у контролі $(\mathrm{P}<0,05)$. У крові риб 3-ї дослідної групи вміст його зменшувався на $3,9 \%$. За застосування препарату “Емамектин-бензоат” вміст гемоглобіну знижувався у крові риб 4-ї групи, будучи на 7,3 \% меншим, ніж у крові контрольних риб. Така ж тенденція до незначного зниження показника гематокриту встановлена у риб всіх дослідних груп. Значні зміни білої крові за змішаної інвазії проявлялися зростанням кількості лейкоцитів. Вірогідно високий рівень лейкоцитів, порівняно 3 контролем, був встановлений у крові риб 2-ї та 4-ї дослідних груп, відповідно на 25,1 (P < 0,01) та $19,2 \%(\mathrm{P}<0,05)$.

\section{Таблиця 1}

Гематологічні показники однорічок коропа, інвазованих ектопаразитами, після застосування препаратів 3 групи макроциклічних лактонів $(\mathrm{M} \pm \mathrm{m}, \mathrm{n}=6)$

\begin{tabular}{|c|c|c|c|c|}
\hline \multirow[b]{2}{*}{ Показники } & \multicolumn{4}{|c|}{ Групи риб } \\
\hline & Контроль & $\begin{array}{c}\text { 0,11-0,26 лерней /г м. т.; } \\
\text { 0,29-0,53 дактилогірусів/г м. т. }\end{array}$ & $\begin{array}{l}\text { Бровермектин- } \\
\text { гранулят }\end{array}$ & $\begin{array}{l}\text { Емамектин- } \\
\text { бензоат }\end{array}$ \\
\hline Еритроцити, Т/л & $1,88 \pm 0,21$ & $0,98 \pm 0,08 * *$ & $1,76 \pm 0,18$ & $1,52 \pm 0,43$ \\
\hline Гемоглобін, г/л & $85,64 \pm 2,45$ & $76,22 \pm 2,54 *$ & $82,32 \pm 3,55$ & $79,35 \pm 3,12$ \\
\hline Гематокрит, л/л & $0,312 \pm 0,08$ & $0,265 \pm 0,05$ & $0,296 \pm 0,04$ & $0,284 \pm 0,07$ \\
\hline Лейкоцити, G/л & $34,56 \pm 2,94$ & $46,12 \pm 1,74 * *$ & $39,24 \pm 2,72$ & $42,76 \pm 1,42 *$ \\
\hline
\end{tabular}

Примітка: *-P <0,05, **-P <0,01, ***-P $<0,001$ щодо показників контролю

Дослідженням вмісту білка та його фракцій за змішаної інвазії та після застосування препаратів групи макроциклічних лактонів встановлено значне зменшення вмісту загального білка у сироватці крові риб 2-ї та 4-ї дослідних груп. За інвазії L. cyprinacea та D. vastator відповідно на $18,4 \%(\mathrm{P}<0,05)$ та після застосування препарату "Емамектин-бензоат" на $12,9 \%(\mathrm{P}<0,05)$. Як свідчать наведені у таблиці 2 дані, вплив змішаної інвазії є специфічним щодо синтезу окремих фракцій білків. На це вказує вірогідно нижчий вміст альбумінів у сироватці крові риб 2-ї дослідної групи на 14,6 \% (P < 0,05). Із даних таблиці випливає, що у сироватці крові риб не встановлено значної різниці у фракційному співвідношенні глобулінів, проте виявлено значне збільшення кількості ßта $\gamma$-глобулінових фракцій за змішаної інвазії риб. Вірогідне зростання ß- та $\gamma$-глобулінових фракцій до показників контрольної групи виявлено у крові риб 2ї дослідної групи відповідно на 19,5 (P $<0,05)$, та $27,2 \%(\mathrm{P}<0,01)$.

Альбуміно-глобуліновий коефіцієнт у сироватці крові риб 2-ї дослідної групи, інвазованих L. cyprinacea та D. vastator, знижувався і становив 0,79, тимчасом як у сироватці крові риб контрольної групи він становив 1,07 .

\section{Таблиця 2}

Відносний вміст білків сироватки крові однорічок коропа, інвазованих ектопаразитами, після застосування препаратів з групи макроциклічних лактонів, $(\mathrm{M} \pm \mathrm{m}, \mathrm{n}=6)$

\begin{tabular}{|c|c|c|c|c|c|}
\hline \multirow{2}{*}{\multicolumn{2}{|c|}{ Показники }} & \multicolumn{4}{|c|}{ Групи риб } \\
\hline & & Контроль & $\begin{array}{c}0,11-0,26 \text { лерней /Г м.т.; } \\
0,29-0,53 \text { дактилогірусів /г м.т. }\end{array}$ & $\begin{array}{l}\text { Бровермектин- } \\
\text { гранулят }\end{array}$ & $\begin{array}{l}\text { Емамектин- } \\
\text { бензоат }\end{array}$ \\
\hline \multirow{2}{*}{\multicolumn{2}{|c|}{$\begin{array}{l}\text { Білок загальний, г/\% } \\
\text { Альбуміни }\end{array}$}} & $39,92 \pm 1,75$ & $32,56 \pm 1,86^{*}$ & $37,28 \pm 2,08$ & $34,76 \pm 1,47^{*}$ \\
\hline & & $51,79 \pm 2,14$ & $44,21 \pm 2,05^{*}$ & $48,67 \pm 2,87$ & $47,92 \pm 2,96$ \\
\hline \multirow{3}{*}{ Глобуліни } & $\alpha$ & $22,30 \pm 1,93$ & $22,24 \pm 2,68$ & $22,86 \pm 2,45$ & $23,32 \pm 2,56$ \\
\hline & B & $15,63 \pm 1,16$ & $19,42 \pm 1,18^{*}$ & $16,78 \pm 1,56$ & $16,12 \pm 1,42$ \\
\hline & $\gamma$ & $10,28 \pm 0,72$ & $14,13 \pm 0,95^{* *}$ & $11,69 \pm 0,92$ & $12,64 \pm 1,23$ \\
\hline А/Г коефіціє & & 1,07 & 0,79 & 0,94 & 0,92 \\
\hline
\end{tabular}

При дослідженні активності амінотрансфераз за змішаної інвазії та після застосування препаратів групи макроциклічних лактонів було встановлено, що активність АлАТ в гепатопанкреасі риб 2-ї, 3-ї та 4-ї груп була значно вищою, порівняно 3 контрольною групою, на 25,5 \% (P < 0,001), 15,4 (P < 0,05) та на 14,7 \% (P < 0,05) відповідно (табл. 3).

Тенденцію до зростання встановлено у тканинах скелетних м'язів. Зокрема, у риб 2-ї дослідної групи активність АлАТ зростала на 21,6 \% (P <0,001). Ак- тивність АлАТ у зябрах риб 2-ї групи була вищою, порівняно 3 контрольною групою, на $14,8 \%$ $(\mathrm{P}<0,05)$.

При дослідженні рівня АсАТ за змішаної інвазії та після застосування препаратів 3 групи макроциклічних лактонів було встановлено, що іiі активність у досліджуваних тканинах гепатопанкресу однорічок коропа 2-ї дослідної групи була вірогідно вищою, ніж у тканинах здорових риб на $18,8 \%$ (Р < 0,01), тимчасом як аналогічна різниця в активності АсАТ у ткани- 
нах скелетних м'язів однорічок коропа 2-ї, 3-ї та 4-ї груп, порівняно з рибами контрольної групи, вірогід- но зростали відповідно на $17,4 \%$ (P $<0,01)$, 9,4 $(\mathrm{P}<0,05)$ та $9,9 \%(\mathrm{P}<0,05)$.

\section{Таблиця 3}

Активність амінотрансфераз у тканинах однорічок коропа, інвазованих ектопаразитами, після застосування препаратів з групи макроциклічних лактонів, $(\mathrm{M} \pm \mathrm{m}, \mathrm{n}=6)$

\begin{tabular}{|c|c|c|c|c|}
\hline \multirow[b]{2}{*}{ Показники } & \multicolumn{4}{|c|}{ Групи риб } \\
\hline & Контроль & $\begin{array}{c}0,11-0,26 \text { лерней /г м.т.; } \\
0,29-0,53 \text { дактилогірусів /г м.т. }\end{array}$ & $\begin{array}{l}\text { Бровермектин- } \\
\text { гранулят }\end{array}$ & $\begin{array}{l}\text { Емамектин- } \\
\text { бензоат }\end{array}$ \\
\hline \multicolumn{5}{|c|}{ Гепатопанкреас } \\
\hline АлАТ, мкмоль/г ткан./год & $118,34 \pm 3,97$ & $158,96 \pm 6,12 * * *$ & $139,85 \pm 5,94 *$ & $138,82 \pm 6,85^{*}$ \\
\hline АсAТ, мкмоль/г ткан./год & $150,24 \pm 7,05$ & $185,12 \pm 7,42 * *$ & $159,56 \pm 6,12$ & $162,75 \pm 6,43$ \\
\hline \multicolumn{5}{|c|}{ Скелетні м'язи } \\
\hline АлАТ, мкмоль/г ткан./год & $215,98 \pm 8,95$ & $275,46 \pm 7,52 * * *$ & $229,65 \pm 6,45$ & $238,46 \pm 7,05$ \\
\hline АсAТ, мкмоль/г ткан./год & $252,18 \pm 8,44$ & $305,16 \pm 9,45^{* *}$ & $278,34 \pm 7,24 *$ & $279,84 \pm 8,58^{*}$ \\
\hline \multicolumn{5}{|c|}{ Зябра } \\
\hline АлАТ, мкмоль/г ткан./год & $164,25 \pm 7,85$ & $192,76 \pm 6,82^{*}$ & $175,84 \pm 5,64$ & $169,82 \pm 7,52$ \\
\hline AcAТ, мкмоль/г ткан./год & $188,24 \pm 9,18$ & $256,75 \pm 9,16^{* * *}$ & $208,64 \pm 8,67$ & $225,54 \pm 8,74 *$ \\
\hline
\end{tabular}

Активність АсАТ у тканинах зябер однорічок коропа 2-ї та 4-ї груп, порівняно з рибами контрольної групи, вірогідно зростала відповідно на 26,7 \% $(\mathrm{P}<0,001)$ та на $16,5 \%(\mathrm{P}<0,05)$.

Отже, аналізуючи морфологічні і біохімічні показники крові, ми можемо констатувати той факт, що протипаразитарні препарати "Бровермектин- гранулят" та "Емамектин-бензоат" виявляють виражену антипаразитарну дію, нормалізуючи гомеостаз організму.

У таблиці 4 наведено лейкоцитарний профіль крові риб за змішаної інвазії та після застосування препаратів групи макроциклічних лактонів.

\section{Таблиця 4}

Лейкоформула крові однорічок коропа, інвазованих ектопаразитами, після застосування препаратів 3 групи макроциклічних лактонів $(\mathrm{M} \pm \mathrm{m}, \mathrm{n}=6)$

\begin{tabular}{lrccc}
\hline \multirow{1}{*}{\multicolumn{1}{c}{ Показники }} & \multicolumn{3}{c}{ Групи риб } \\
\cline { 2 - 5 } & Контроль & $\begin{array}{c}0,11-0,26 \text { лерней/г м.т.; } \\
0,29-0,53 \text { дактилогірусів/г м.т. }\end{array}$ & $\begin{array}{c}\text { Бровермектин- } \\
\text { гранулят }\end{array}$ & $\begin{array}{c}\text { Емамектин- } \\
\text { бензоат }\end{array}$ \\
\hline Еозинофіли & $1,52 \pm 0,34$ & $3,24 \pm 0,32^{* *}$ & $2,65 \pm 0,14^{*}$ & $2,87 \pm 0,38^{*}$ \\
Паличкоядерні нейтрофіли & $1,56 \pm 0,32$ & $2,98 \pm 0,28^{* *}$ & $2,74 \pm 0,32^{*}$ & $2,55 \pm 0,27^{*}$ \\
Сегментоядерні нейтрофіли & $0,85 \pm 0,05$ & $0,65 \pm 0,07^{*}$ & $0,74 \pm 0,04$ & $0,69 \pm 0,02^{*}$ \\
Базофіли & $2,15 \pm 0,42$ & $2,18 \pm 0,25$ & $2,28 \pm 0,23$ & $2,54 \pm 0,34$ \\
Моноцити & $3,95 \pm 0,56$ & $5,12 \pm 0,96$ & $4,45 \pm 0,94$ & $4,85 \pm 0,86$ \\
Лімфоцити & $87,17 \pm 1,62$ & $80,44 \pm 2,42^{*}$ & $84,65 \pm 3,52$ & $80,62 \pm 2,34^{*}$ \\
\hline
\end{tabular}

Виявляли вірогідне зростання еозинофілів у крові риб 2-ї, 3-ї та 4-ї дослідних груп відповідно на 53,1 \% $(\mathrm{P}<0,01), 42,6(\mathrm{P}<0,05)$ та 47,0\% $(\mathrm{P}<0,05)$. Кількість паличкоядерних нейтрофілів була вищою, порівняно з контролем, у крові риб 2-ї дослідної групи на 47,7 \% (P < 0,01), 3-ї - на 43,1 (P < 0,05), 4-ї - 38,8 \% $(\mathrm{P}<0,05)$.

За змішаної інвазії, поряд зі зростанням кількості паличкоядерних нейтрофілів, зменшується вміст сегментоядерних нейтрофілів у крові коропів. У крові риб 2-ї дослідної групи вміст сегментоядерних нейтрофілів становив $0,65 \pm 0,07$ проти $0,85 \pm 0,05$ у контролі $(\mathrm{P}<0,05)$. У крові риб 4-ї дослідної групи вміст зменшувався на $18,8 \%$ ( $<0,05)$.

За змішаної інвазії риб ектопаразитами та після застосування препаратів з групи макроциклічних лактонів встановлено явище лімфопенії, зокрема у риб 2-ї та 4-ї дослідних груп кількість лімфоцитів вірогідно знижувалася на 7,7 (P <0,05) та 7,5 \% $(\mathrm{P}<0,05)$.

Отримані результати показали вірогідні коливання кількості нейтрофілів, еозинофілів та лімфоцитів. Зміна частки вмісту нейтрофілів в основному відбувається за рахунок паличкоядерних клітин. У інвазованих ектопаразитами риб, яким застосовували препарати $з$ групи макроциклічних лактонів, у лейкоцитарній формулі різко зростає відсоток паличкоядерних нейтрофілів і одночасно знижується частка лімфоцитів. Водночас відбувається зростання кількості еозинофілів, які виконують функцію захисту організму риб від паразитів. Еозинофілія, як і у вищих хребетних, $є$ одним $з$ об'єктивних показників алергізації (сенсибілізації) організму, характеру перебігу запальних процесів.

За змішаного ураженння риб $L$. cyprinacea та D. vastator та після застосування препаратів 3 групи макроциклічних лактонів кількість загальних Тлімфоцитів вірогідно знижувалася у крові риб 2-ї, 3-ї та 4-ї груп (табл. 5) відповідно на 19,9 \% (P < 0,01), $16,4(\mathrm{P}<0,01)$ та $11,4 \%(\mathrm{P}<0,05)$.

Кількість Т-лімфоцитів хелперів також вірогідно 
знижувалася у крові риб 2-ї та 3-ї дослідних груп на $22,7(\mathrm{P}<0,01)$ та $18,4 \%(\mathrm{P}<0,05)$.

За змішаної інвазії риб ектопаразитами встановле- но незначне зниження числа Т-лімфоцитів супресорів та водночас вірогідне зростання числа В-лімфоцитів у крові риб 2-ї дослідної групи на 13,0% (P < 0,05).

\section{Таблиця 5}

Кількість Т- і В-лімфоцитів у крові однорічок коропа, інвазованих ектопаразитами, після застосування препаратів з групи макроциклічних лактонів $(\mathrm{M} \pm \mathrm{m}, \mathrm{n}=6)$

\begin{tabular}{lcccc}
\hline \multirow{1}{*}{\multicolumn{1}{c}{ Показники }} & \multicolumn{4}{c}{ Групи риб } \\
\cline { 2 - 5 } & \multirow{2}{*}{ Контроль } & $\begin{array}{c}0,11-0,26 \text { лерней /г м.т.; } \\
0,29-0,53 \text { дактилогірусів /г м.т. }\end{array}$ & $\begin{array}{c}\text { Бровермектин- } \\
\text { гранулят }\end{array}$ & $\begin{array}{c}\text { Емамектин- } \\
\text { бензоат }\end{array}$ \\
\hline Загальні Т-лімфоцити, \% & $44,55 \pm 1,43$ & $35,68 \pm 1,54 * *$ & $37,25 \pm 1,52^{* *}$ & $39,45 \pm 1,35^{*}$ \\
Активні Т-лімфоцити, \% & $37,68 \pm 1,75$ & $39,64 \pm 1,32$ & $37,42 \pm 1,28$ & $38,15 \pm 1,52$ \\
Т-лімфоцити & $34,85 \pm 2,04$ & $26,95 \pm 1,16^{* *}$ & $28,42 \pm 1,62 *$ & $30,65 \pm 1,46$ \\
хелпери, \% & & & & \\
Т-лімфоцити & $9,70 \pm 1,08$ & $8,73 \pm 1,14$ & $8,83 \pm 1,18$ & $8,80 \pm 1,05$ \\
супресори, \% & $27,45 \pm 1,26$ & $31,56 \pm 1,28^{*}$ & $30,12 \pm 1,53$ & $30,48 \pm 1,69$ \\
В-лімфоцити, \% & & & & \\
\hline
\end{tabular}

Одержані результати свідчать про зменшення продукції загальних Т-лімфоцитів - клітин, які відіграють ключову роль у системі імунного захисту в організмі коропа за ураження ектопаразитами. Ці відмінності можна пояснити негативною дією ектопаразитів на імунну резистентність риб.

При аналізі наведених у таблиці даних привертає увагу нижча функціональна активність системи Тлімфоцитів крові у інвазованих ектопаразитами риб, ніж у тих, яким задавали протипаразитарні препарати.
3 цього випливає, що здатність лімфоцитів крові риб, яким задавали препарати 3 групи макроциклічних лактонів, до зв'язування антигенів патогенів і продукції антитіл, які їх знешкоджують, значно вища, ніж у риб, уражених ектопаразитами.

За змішаного ураженння риб $L$. cyprinacea та D. vastator та після застосування препаратів 3 групи макроциклічних лактонів лізоцимна активність вірогідно знижувалася у крові риб 2-ї та 4-ї груп (табл. 6) відповідно на 18,9 (P < 0,05) та 8,6 \% $(\mathrm{P}<0,05)$.

\section{Таблиця 6}

Показники неспецифічної резистентності у крові однорічок, інвазованих ектопаразитами, після застосування препаратів з групи макроциклічних лактонів $(\mathrm{M} \pm \mathrm{m}, \mathrm{n}=6)$

\begin{tabular}{|c|c|c|c|c|}
\hline \multirow[b]{2}{*}{ Показники } & \multicolumn{4}{|c|}{ Групи риб } \\
\hline & Контроль & $\begin{array}{c}0,11-0,26 \text { лерней /г м. т.; } \\
0,29-0,53 \text { дактилогірусів /Г м. т. }\end{array}$ & $\begin{array}{c}\text { Бровермектин- } \\
\text { гранулят }\end{array}$ & $\begin{array}{c}\text { Емамектин- } \\
\text { бензоат }\end{array}$ \\
\hline Лізоцимна активність, \% & $40,12 \pm 1,84$ & $32,54 \pm 1,85^{*}$ & $36,65 \pm 1,98$ & $34,76 \pm 1,52 *$ \\
\hline Бактерицидна активність, \% & $32,14 \pm 1,95$ & $25,56 \pm 1,68^{*}$ & $30,42 \pm 2,04$ & $29,95 \pm 1,85$ \\
\hline Фагоцитарна активність, \% & $37,98 \pm 1,78$ & $32,45 \pm 1,44^{*}$ & $35,85 \pm 1,37$ & $35,74 \pm 2,14$ \\
\hline Фагоцитарний індекс, од. & $10,24 \pm 0,96$ & $8,52 \pm 0,85$ & $9,48 \pm 1,12$ & $8,76 \pm 1,07$ \\
\hline Фагоцитарне число, од. & $6,42 \pm 0,84$ & $3,56 \pm 0,62 *$ & $4,15 \pm 0,54^{*}$ & $5,18 \pm 0,65$ \\
\hline
\end{tabular}

Бактерицидна активність також знижувалася, проте вірогідне зниження виявляли тільки у крові 2-ї дослідної групи риб на 20,5 \% (Р<0,05).

За змішаної інвазії риб ектопаразитами встановлено вірогідне зниження фагоцитарної активності на $14,6 \%(\mathrm{P}<0,05)$. Водночас відмічали вірогідне зниження фагоцитарного числа у крові риб 2-ї та 3-ї дослідних груп на 44,5 (P <0,05) та $35,4 \%(\mathrm{P}<0,05)$ відповідно.

Імунна система у риб забезпечує саморегуляцію за допомогою безпосереднього контакту клітин (макрофагів, нейтрофілів, цитотоксичних Т-лімфоцитів), а також завдяки гуморальним факторам (лізоциму, комплементу). Застосування препаратів з групи макроциклічних лактонів сприяє звільненню інвазованих риб від ектопаразитів 3 подальшою нормалізацією їхньої життєдіяльності, підвищенню імунного статусу і резистентності.

\section{Висновки}

За змішаної інвазії кількість еритроцитів була меншою, порівняно з контролем, у крові риб 2-ї дослідної групи на 47,9%. Вірогідно високий рівень лейкоцитів, порівняно 3 контролем, встановлений у крові риб 2-ї та 4-ї дослідних груп відповідно на 25,1 та $19,2 \%$.

Встановлено значне зменшення вмісту загального білка у сироватці крові риб 2-ї та 4-ї дослідних груп відповідно на 18,4 \% та 12,9 \%. Вірогідне зростання ßта $\gamma$-глобулінових фракцій щодо показників контрольної групи виявлено у крові риб 2-ї дослідної групи відповідно на 19,5 та 27,2 \%.

Активність АлАТ в гепатопанкреасі риб 2-ї, 3-ї та 4-ї груп була значно вищою, порівняно з контрольною групою, на 25,5 \%, 15,4 та на 14,7\% відповідно. У скелетних м'язах та зябрах риб 2-ї дослідної групи активність АлАТ зростала на 21,6 \% та 14,8 \%. 
При дослідженні рівня АсАТ було встановлено, що іiі активність у досліджуваних тканинах гепатопанкресу однорічок коропа 2-ї дослідної групи була вірогідно вищою, ніж у тканинах здорових риб, на $18,8 \%$. Активність АсАТ у тканинах скелетних м'язів однорічок коропа 2-ї, 3-ї та 4-ї груп, порівняно $з$ рибами контрольної групи, вірогідно зростали відповідно на $17,4 \%$, 9,4 та 9,9\%. АсАТ у тканинах зябер однорічок коропа 2-ї та 4-ї груп, порівняно з рибами контрольної групи, вірогідно зростала на 26,7 \% та $16,5 \%$.

Виявляли вірогідне зростання еозинофілів у крові риб 2-ї, 3-ї та 4-ї дослідних груп відповідно на 53,1 \%, 42,6 та 47,0 \%. Кількість паличкоядерних нейтрофілів була вищою, порівняно з контролем, у крові риб 2-ї дослідної групи на 47,7 \%, 3-ї - на 43,1, 4-ї - на $38,8 \%$.

За змішаного ураженння риб L. cyprinacea та D. vastator та після застосування препаратів 3 групи макроциклічних лактонів кількість загальних Тлімфоцитів вірогідно знижувалася у крові риб 2-ї, 3-і та 4-ї груп відповідно на 19,9, 16,4 та 11,4 \%. Кількість Т-лімфоцитів хелперів також вірогідно знижувалася у крові риб 2-ї та 3-ї дослідних груп на 22,7 та $18,4 \%$.

Лізоцимна активність вірогідно знижувалася у крові риб 2-ї та 4-ї груп відповідно на 18,9 та 8,6 \%. Бактерицидна активність також знижувалася у крові 2-ї дослідної групи риб на 20,5 \%. Встановлено вірогідне зниження фагоцитарної активності на 14,6\%. Водночас виявляли вірогідне зниження фагоцитарного числа у крові риб 2-ї та 3-ї дослідних груп на 44,5 та 35,4 \% відповідно.

Перспективи подальших досліджень. У зв'язку 3 одержаними результатами виникає потреба дослідити ефективність пропонованої схеми застосування препаратів у виробничому досліді.

\section{References}

Bauer, O. N. (1987). Opredelitel' parazitov presnovodnyh ryb fauny SSSR: V 3t. Paraziticheskie mnogokletochnye. Lenigrad: Nauka, 3(2), 584 (in Russian).

Byhovskaja-Pavlovskaja, E. I. (1985). Parazity ryb. Rukovodstvo po izucheniju. L.: Nauka (in Russian).

Chumachenko,V. E. (1990). Opredelenie estestvennoj rezistentnosti i obmena veshhestv u sel'skohozjajstvennyh zhivotnyh. Kiev: Urozhaj (in Russian).
Dekhtiarov, P. A. (2008). Fiziolohiia ryb. K.: Ahrarna osvita (in Ukrainian).

Dorofejchuk, V. G. (1968). Lizocimnaja aktivnost' syvorotki krovi. Lab. Delo, 1, 28-34 (in Russian).

Hemaprasanth, K. P., Kar B., Garnayak, S. K., Mohanty, J., Jena, J. K., \& Sahoo, P. K. (2012). Efficacy of two avermectins, doramectin and ivermectin against Argulus siamensis infestation in Indian major carp, Labeo rohita. Vet. Parasitol, 190(1-2), 297-304. doi: 10.1016/j.vetpar.2012.05.010.

Horsberg, T. E. (2012). Avermectin use in aquaculture. Curr. Pharm. Biotechnol., 13(6), 1095-1102. doi: 10.2174/138920112800399158.

Ivanov, A. A. (2003). Fiziologija ryb. Moskva: Mir (in Russian).

Kondrahin, I. P. (1985). Klinicheskaja laboratornaja diagnostika $\mathrm{v}$ veterinarii. Spravochnoe izdanie. Moskva: Agropromizdat (in Russian).

Loboiko, Yu. V., \& Danko, M. M. (2015). Terapevtychna ta ekonomichna efektyvnist zastosuvannia brovermektyn-hranuliatu za ektoparazytoziv koropa. Naukovyi visnyk Lvivskoho NUVMB imeni S. Z. Gzhytskoho, 17, 2(62), 124-130. http://nbuv.gov.ua/UJRN/nvlnu 2015_17_2_28 (in Ukrainian).

Loboiko, Yu. V., Stybel, V. V., \& Danko, M. M. (2016). Terapevtychna efektyvnist protyparazytarnykh preparativ $\mathrm{z}$ hrupy makrotsyklichnykh laktoniv ta imunomoduliatora za lerneozu koropa. Biolohiia tvaryn, 18(1) 87-92. doi: 10.15407/animbiol18.01.087 (in Ukrainian).

Novikov, D. K., \& Novikova, V. I. (1979). Kletochnye metody immunodiagnostiki. Minsk: Zdorov'e (in Russian).

Osadchaja, L. M. (1982). Opredelenie aktivnosti aminotransferaz $\mathrm{v}$ tkanjah. Metody biohimicheskih issledovanij (lipidnyj i jenergeticheskij obmen). Leningrad (in Russian).

Tisler, T., \& Kozuh-Erzen, N. (2006). Abamectin in the aquatic environment. Ecotoxicology, 15, 495-502. doi: 10.1007/s10646-006-0085-1.

Veldhoen, N. (2012). Biological effects of the antiparasitic chemotherapeutant emamectin benzoate on a non-target crustacean, the spot prawn (Pandalus platyceros Brandt, 1851) under laboratory conditions. Aquat. Tox., 108, 94-105. doi: 10.1016/ j.aquatox.2011.10.015.

Vlizlo, V. V. (2012). Laboratorni metody doslidzhen u biolohii, tvarynnytstvi ta veterynarnii medytsyni. Dovidnyk. Lviv : Spolom (in Ukrainian). 